\title{
Experiences of pre-service English teachers gained through community service learning in kindergartens
}

\author{
Gülşah Külekçi* \\ Department of English Language and Teaching, Dokuz Eylül University Education Faculty, \\ İzmir, Turkey
}

\section{Article history}

\section{Received:}

04.05.2014

Received in revised form: 03.06.2014

Accepted:

05.06.2014

Key words:

Pre-service English teachers, community service learning, kindergartens
Many authors agree that community service learning should be integrated into pre-service teacher education in order to achieve the maximum positive impact on the next generation of teachers. This study aims at inquiring the experiences of pre-service English teachers gained through community service learning. The study is based on qualitative case study design. Qualitative data were collected using participant portfolios from 40 pre-service English teachers in ELT Department who kept portfolios throughout their observations of eleven weeks. The data were analyzed using qualitative content analysis method by coding and creating categories/themes. Results showed that pre-service teachers faced some problems during the process of community service. However, their practices through community service learning in kindergartens helped them gain various experiences which will contribute a lot to their future teaching careers. The evaluative feedback stressed marked improvement in the quality of the student learning and engagement experiences. It is hoped that the experiences of preservice English teachers engaged in the portfolio development process will help other educators who are implementing portfolios within teacher education programs. The results of this study also provide important information for both policy-makers interested in the reform of pre-service teacher education and practicing teacher educators focused on achieving the goals of pre-service teacher education through the use of community service learning. 


\section{Introduction}

Teaching English to Young Learners (TEYL) is a rapidly growing field around the world, and English education is increasingly found at the primary levels. Recent trends in Turkey's educational policy have focused on meeting the challenges of globalization and internationalization. As English has achieved the status of a major international language, the government of Turkey has been actively expanding the teaching of English as an essential part of the school curriculum. Today, English education is a required course for second graders in elementary school. Moreover, there are attempts to change the English teaching policy to require that elementary school students begin their English learning from the first grade onward. One real advantage of having children start learning English at an early age is that they are better equipped to develop English language acquisition. It is also maintained that acquirers who begin exposure to second language during childhood are believed to achieve higher second language proficiency in the long run than those beginning as adults (Krashen et al., 1979; Long, 1990). According to the findings of these studies the area responsible for language learning goes through a furious growth from around age 5 to the onset of puberty.

The EFL curriculum for young learners in Turkey has been renewed and implemented in 2013-2014 school year and this new curriculum, developed by the Ministry of National Education, favors the principles of a constructivist understanding with a learner centered, process oriented and task-based approach using various communicative activities (MoNE, 2013). Given all these efforts to provide young learners with English as early as possible, the main challenge seems to make sure that the instruction they receive is developmentally appropriate, pedagogically sound and culturally responsive (Koller, 2006). In order to meet all these demands, we should be sure that pre-service English teachers learn all the things necessary for being a qualified teacher and gain various experiences which will contribute a lot to their future teaching careers. Pre-service English teachers take some compulsory courses such as Approaches and Methods in ELT, Teaching Technologies and Material Design, Principles and Methods of Teaching, Classroom Management, Teaching Young Learners, School Experience and Teaching Practice, during their four year academic training. The problem is that, they do not have enough chance to apply the things they have learnt. In their third year, pre-service English teachers have a course entitled "Community Service Learning" which is designed to enhance pre-service-teachers' empowerment through their work with community service learning projects like working willingly in public elementary school classrooms and kindergartens. Empowerment in student teaching is characterized by initiative, leadership, assertiveness, creativity, and recognition of one's success (Wade, 1997). Since community service teaching provides such an opportunity for the pre-service teachers, it can also give them a chance to improve their skills in teaching young learners in primary public schools. Within this framework, the present study aims at inquiring the possible problems and difficulties facing pre-service English teachers in teaching English to children, specifically in kindergartens. Thus, the practices of pre-service English teachers during their community service teaching are illustrated in detail in an illustrative case study design.

\section{Literature Review}

\subsection{Teaching Young Learners}

Many theorists and practitioners believe that there are some benefits of beginning to learn English at an early age: 
- to develop language awareness

- to encourage motivation and interest in language learning

- to learn about other cultures

- to provide more opportunities for English learning at school

It is important to remember that an early start alone will not necessarily improve children's ability to learn English. It is also very important that L2 instruction include language structures that are presented within a context that is meaningful and communicative.

Carol Read (2005) suggests that the seven Rs provide an integrated framework for managing children positively:

- Relationships - creating and maintaining a positive relationship with learners is at the heart of establishing a happy learning environment.

- Rules - establish a limited number of rules and make sure they are clear, as well as the reasons for having them.

- Routines - classroom routines make it clear to everyone what is expected of them and what they should do.

- Rights and Responsibilities - although these may not be stated explicitly with very young learners, teachers can model through their own actions which of these they value.

- Respect - students who are treated respectfully by the teacher will respond in a similar way to the teacher. If the children feel that the teacher treats them as individuals, they will also respond to the teacher as an individual and not with a collective group mentality.

- Rewards - reward systems can be an effective way of reinforcing appropriate behavior e.g. using stars, stickers, points, smiley faces, raffle tickets or marbles in a jar.

Young children are active learners. They are open to new experiences. They are imaginative and explorative. They 'learn by doing', for example through play, movement, and interaction with others. In a similar vein, Scott and Ytreberg (1990) argue that young learners' own understanding comes through hands and eyes and ears, and the physical world is dominant at all times. Using brightly colored visuals, toys, puppets or other objects will work well with young children. Craft activities such as painting, origami and play doughs can be physically satisfying for the young learners. It is also great to use songs, chants and poems in the classroom. A variety of activities with different paces and tempos are necessary since children have a short attention span (Scott \& Ytreberg, 2001; Shin, 2006). Role of motivation for young learners in foreign language education has been studied extensively so far (Cameron, 2001; Chambers, 1999). It is a common fact that it is impossible for learners to go on with their learning process effectively if they feel demotivated. Demotivated learners may have poor concentration and low self- esteem. The motto should be learning by enjoying, and the more fun the students have the better they will remember the language learned (Shin, 2006). Children have a set of characteristics that facilitate the learning of another language besides 
their mother tongue. These include few inhibitions, low level of anxiety, higher enthusiasm in game-like activities, and higher skills in imitating models and patterns. In this process, the teacher's role is highly demanding. They should adapt their language, teaching techniques and methods, and the emotional, cognitive and physical atmosphere in the classroom according to the children's needs and readiness in order to achieve an effective learning.

There is a wide consensus (Biricik \& Özkan, 2012) that teachers should give proper and comprehensible instructions and use the mother tongue to make the statements much clearer to young learners. As these young learners are not proficient even in their mother tongue, we cannot expect them to fully understand the instructions given in the target language. So, it is inevitable for the teacher to use their native language in the classroom.

As young learners enroll in kindergartens in record numbers, educators must continually strive to provide effective, nurturing environments and developmentally appropriate instruction for all learners. This instruction should take into consideration the characteristics of young English language learners, the learning conditions that are most effective for them, and the kinds of instruction that best meet their needs.

\subsection{Community Service-Learning in Teacher Education}

Community service - learning may be described as both a philosophy of education and an instructional method. As a philosophy of education, service-learning reflects the belief that education should help students develop personally while also enhancing their social responsibility through preparation for active citizenship in a democratic society. As an instructional method, service- learning involves a blending of service activities with the academic curriculum in order to address real community needs while students learn through active engagement and reflection (Cairn \& Kielsmeier, 1991).

Community service -learning is also proliferating in teacher education programs throughout Turkey. In Turkey, over 100 teacher education programs offer students service - learning experiences and these programs are interested in developing such opportunities for preservice teachers. The prospective teachers in these programs typically engage in servicelearning by working with children in need through schools and community agencies, assisting teachers and developing service-learning activities for use during student teaching. Educators at all levels report that well-designed and implemented service-learning activities can help address these concerns while simultaneously providing students opportunities for enhancing academic knowledge and skills and personal growth (Root, 1997). Teacher educators cite the following reasons for integrating community service-learning into their courses (Anderson \& Guest, 1993):

- To help socialize teachers in the essential moral and civic obligations of teaching, including teaching with care, adapting to the needs of learners with diverse and special needs;

- To enhance pre-service teachers' ability to reflect critically on current educational practices and their own teaching;

- To accelerate the process of learning how to perform a variety of roles needed to meet the needs of students such as counselor, advocate, moral leader, etc.;

- To develop human service oriented teachers who can work effectively in schools with integrated services or other social service settings. 
Briefly, community service learning is recognized as having the potential to develop students' academic, cognitive, interpersonal and human relationship skills (Strage, 2004; Closson \& Mullins Nelson, 2009). It also affords students opportunities to apply their classroom learning to real-life context, develop an appreciation of the relevance of classroom learning. Indeed, Weglarz and Seybert (2004) found that a major benefit of community service learning is the opportunity for practical application of theory/course content. Community service-learning involves the key elements of community service and intern-ships so both the service providers and the service recipients benefit. These benefits result from a dual focus on the service being provided and the learning that will occur. Educators at all levels report that well-designed and implemented community service-learning activities can help address unmet community needs while simultaneously providing students the opportunity to gain academic knowledge and skills. Wade (1995) noted an increase in pre-service teachers' positive attitudes about community participation, and gains in self-esteem and self-efficacy. Seigel (1995) concluded that teacher education students who completed a community service experience increased their sensitivity to diversity and became more insightful about their own responses to diverse students.

A number of studies have determined that teacher education students have largely positive experiences with community service learning (Anderson \& Guest, 1993; Boyle-Baise, 1997; Wade \& Yarbrough, 1997). Initial research results, teacher educators and pre-service teachers all suggest that community service-learning can be a worthwhile and powerful learning experience. Within this framework, the present study aims at examining the pre-service teachers' experiences while teaching young learners during their community service learning, specifically in kindergartens in state schools.

\section{Method}

\subsection{Participants}

The data for this study is drawn from those 40 students, 14 of whom were male and 26 of whom were female. During the first semester of the 2012-2013 school year, ELT student teachers enrolled at a state university in Izmir, Turkey were required to engage in one form of community service. The minimum requirement for this activity was 30 hours. Students were required to submit reflections on their community service experiences as a portfolio at 4 elementary practice schools determined officially. During a period of 11 weeks they performed their community service. The classes they attended were composed of rather young learners, children at the age of 5 .

\subsection{Data Collection}

Pre-service English teachers were asked to complete a community service learning portfolio which has the following components: the aims and objectives of the activities they prepared for each week, the duration of the activity, materials used for the activity, how they felt before and after the activity, the difficulties they faced during the activity and their reflections about the benefits of community service learning. The guidelines for the personal reflections were also broad, allowing students to reflect on any aspect of the experience that they thought appropriate. Participants were encouraged to write their portfolios weekly and hand them to the researcher on a regular basis. Each participant handed a portfolio of eleven papers to the researcher at the end of the semester. 


\subsection{Data Analysis}

The data were analyzed using qualitative content analysis method by coding and creating categories/themes. Creswell's (2002) strategy was followed for the coding process. A preliminary exploratory analysis was conducted to obtain a general sense of the data and think about the organization of the data. The text was divided into segments of information with codes. In subsequent analyses, these codes were reduced to a few major themes through the process of eliminating redundancies and codes that could not be conveniently categorized. As a strategy for enhancing the validity of the findings (Creswell, 2002), a colleague conducted a thorough review of the study and reported back in writing the strengths and weaknesses of the analysis. In the spirit of authenticity, no corrections were made in the participants' use of grammar or vocabulary. The names used in this article are pseudonyms.

\section{Findings}

In this present study, two specific core themes and their subthemes, which offered something unique to the research literature, are addressed in the data. The emerging core themes and their subthemes are presented and commented using direct quotations from the participants.

\section{Core theme: Experiences gained through community service learning in terms of teaching young learners}

Related to this core theme, four subthemes are presented and commented: lack of concentration and motivation, classroom management (discipline problems) and overcrowded classes, individual differences and insufficient physical conditions.

\section{Subthemes:}

\section{Lack of concentration and motivation}

A systematic analysis of the journal entries about the comments on lack of concentration and getting bored easily revealed that children have a short attention span. One participant, Emre, shared his experiences in his portfolio and explained how he motivated his students:

As far as I have observed, kids become more motivated when they see the teacher, energetic, jumping, and/or walking around the class. They also like funny teachers. They love making funny noises. Although a bit tiring, I try to be as energetic as possible. Oh! Hard work....

In some cases, especially with Serpil, it proved that the objective to motivate young learners can be achieved pedagogically:

When we use materials such as English cartoons and songs and play simple English games, students get motivated and indulged in the lesson. I think, they are willing and enthusiastic about learning English.

Similarly, Gizem stated: 
The world of the imagination is vivid and real to these children, so they move easily in and out of a world where animals talk or activities take place on a magical trip to another world.

Ezgi's comments are also striking:

Because they are very self centered, they do not work well in groups, and they respond best to activities and learning situations relating to their own interests and experiences. Although they have a short attention span, they have great patience for repetition of the same activity or game. Preschoolers respond well to concrete experiences and to large-motor involvement in language learning.

\section{Classroom management (discipline problems) and overcrowded classes}

Naturally, the participants were not experienced in classroom management and they found it difficult to cope with discipline problems. Moreover, the classes were overcrowded which made the situation harder for the participants as Esra stated:

I am making remarkable effort to teach English, but unfortunately I cannot sustain silence in such a crowded class.

Some participants tried to find a solution to calm down some naughty students in the class and the activities they planned worked well. Caner described the process:

It is a good idea to always carry an extra "life saving" activity. No matter how wonderful your activities for the day are and how great your expertise is, some days will be rough. In days like this I would take out a bag of play-dough or another tactile activity and postpone my wonderful plans to the next day. That's how it is.

\section{Individual differences}

A good deal of portfolio entries was categorized about individual differences, mainly in terms of learning styles and learning strategies. There was a general agreement on inadequacy of teachers to meet the needs resulting from the individual differences.

Şule's reflection indicated these differences:

Some learners thrive in a highly social and interactive environment; others feel more comfortable and may do better when they can think and learn alone. Some learners are motivated and empowered by carefully structured, linear tasks and unvarying routines; they may find it annoying and distracting when bulletin boards or visuals are not carefully aligned and the classroom isn't neat and orderly.

Umut's ideas about individual differences also support the same situation:

Other students feel suffocated by so much structure and long for the freedom to solve problems and be creative. These same students enjoy classes in which the teacher keeps them guessing and sometimes makes random leaps from one topic to another. These students don't usually mind a little clutter - it makes them feel at home!

Amazingly, Esra's observations are parallel with her friends' observations: 
Many students need a supportive emotional climate in which to learn, and regular assurance that they are valued as people, regardless of their performance. A few students, on the other hand, just want to be left alone to learn-on their own! Some students need to touch, or move, in order to learn. (That's probably true of almost every primary school child.)

In a related manner, Zeki stated:

Some students benefit most from visuals and teachers' gestures when they are learning or reviewing language; others won't feel confident of the information until they see it written out; still others, with poor vision or a brain that processes visual input poorly, don't benefit from either.

\section{Insufficient physical conditions}

Most of the pre-service teachers agreed that the physical conditions of the school were not appropriate for kindergarten children. Walls, curtains, desks and board were colorless and toys were not interesting enough.

One pre-service teacher, Özge, complained:

When I entered the class the first day, I was shocked by the size of the class. It was too small. I thought it would be difficult to organize games or such things ... The class was also so dim. It needed some more light, I think.

Zeki also thought in the same way:

My friends and I couldn't concentrate on what we were doing because of the oldfashioned furniture and the depressing atmosphere in the class. If we had the chance, we would have painted all the walls, for instance.

\section{Core theme: Experiences gained through community service learning in terms of teaching methodology}

Related to this core theme, six subthemes are presented and commented: gaining confidence, realizing their own deficiencies and self-evaluating themselves, the use of the mother tongue, preparing suitable materials, lack of technology and technical problems and communicating with children and learning about child psychology.

\section{Subthemes:}

\section{Gaining confidence}

One of the advantages of community service learning was that pre-service teachers gained confidence in their teaching English to young learners.

Zeki, for example, stated:

My community service learning experience was tiring but amazing at the same time. Before that I had thought that I could do nothing with such small children. However, it was not so. Day by day, I discovered the potential inside me and I became more confident. I was relaxed and felt good. 
Ozan also supported a similar idea:

Before my experience in this kindergarten, I wasn't aware of my potential. I was afraid and not confident. But now, I know that I learned many things about young learners and can teach them many things.

\section{Realizing their own deficiencies and self-evaluating themselves}

Through community service learning, pre-service English teachers realized their own deficiencies and this led to self-evaluating themselves. Community service learning was their only contact with small children and they practiced all the theoretical knowledge they had learned in their courses. They also had the opportunity to observe the classroom teacher in the class. One of the pre-service teachers emphasized the role of the classroom teacher in this process and described how the support she received from the classroom teacher positively influenced her:

The classroom teacher's behavior and the relationship between the teacher and the student affect the student's motivation towards the lesson. Teacher behavior is a motivational tool. I've observed the classroom teacher's behaviors and gained experiences form her. Cooperation with her worked well.

In addition, Serpil pointed out:

The key point is to establish a relationship of mutual trust and respect with learners. This situation may lead to enthusiasm. It seems hard to achieve this. But, I think, I can do it. I need some time...

Simay, also expressed her ideas:

As I studied with young learners, I learned to be patient. Normally, I am impatient and a bit nervous. But these small children taught me to be patient and tolerant. I repeated the same thing maybe four or five times to them till they learn.

It is possible that some of the challenges pre-service teachers faced resulted from their being inexperienced about teaching young learners. However, they succeeded in overcoming their deficiencies.

\section{The Use of the Mother Tongue}

A systematic analysis of the journal entries about the comments on the use of the mother tongue revealed that the mother tongue gives an opportunity to clarify the meaning and reduces student anxiety. Participants believe that teachers need to tolerate a certain amount of mother tongue, as long as it is accompanied by attempts at producing target language output.

As Emre pointed out:

I used L1 in the classroom as a resource for forwarding the learning process without becoming too reliant on it. I tried to concentrate on building communicative skills. So that, I saved time for the target language actually within students' reach. 
Aslı also shares her experiences:

When I realized that the students didn't understand what I said, I quickly made a difficult expression comprehensible by translating it into the mother tongue. To be honest, I used the mother tongue for complicated directions for activities.

\section{Preparing suitable materials}

Kindergarten learners are both curious and willing to learn new things. Therefore, English courses for them should not adhere to only books; on the contrary the courses should be enriched by using additional instructional materials. English courses should be supported by songs, real objects, games, cartoons, videos, CDs, etc.

As Derya pointed out:

Teaching English to young learners was really enjoyable, but tiring at the same time. Play, play, play! My first grade students enjoy creating and playing games that reinforce whatever language elements we are working on. Games that involve closing eyes and hiding objects are especially successful.

The pre-service English teachers found it rather difficult at first to prepare suitable instructional materials. However, as they gained experience each week, they found materials to attract young learners' attention.

\section{Lack of technology and technical problems}

The portfolio entries by most of the participants repeatedly pointed to the lack of suitable facilities, technologies and materials, as Koray illustrated:

My first technology use with the young learners was an extraordinary moment.........To illustrate simply, when I attempted to turn on the computer it did not work. The CD player was also not working.

In a related manner, Asli indicated that she had many problems while she was doing the listening activities:

I had prepared various listening activities before I came to the class. However, as I entered the class, the classroom teacher said that the CD player had not been working for weeks. So, all my listening activities were read by me. Oh! What a shame...

Cemre also described the process:

The first day I entered the class I was a bit nervous since it was my first experience with small children. I knew for certain that listening to some songs would be useful and attractive for the children. I had a good Cd in my bag and decided to teach them a lovely song about numbers. As I attempted to turn on the computer I realized that it was not working. What I felt was a cold shower over me...

Almost all of the participants are found to have criticisms against poor technological conditions. 


\section{Communicating with children and learning about child psychology}

Almost all of the participants believed that learning about child psychology is crucial in teaching young learners. Providing a safe, entertaining and educational environment and making them feel competent and confident while learning English are the key points in keeping them motivated.

Asli, for example, stated:

There is no distance between me and children. To be honest, I am affectionate to them. They feel comfortable and relaxed. They are not afraid of me. I sit by them ...... I call them with pleasant nicknames.

Another pre-service English teacher, Demet, explained that communication was a very sensitive topic, and echoed Aslı's thoughts:

Children generally seem to love me because I do not get angry. I have established a good rapport with them. They feel themselves secure. They are not afraid while answering questions because they know I will not get angry and scold in case of a wrong answer.

As Filiz illustrated:

They need to feel accepted, liked, part of the group, and to be noticed and smiled at by the teacher. Feeling uncomfortable in class makes them physically sick (tummy ache). They like to move constantly, manipulate three-dimensional things, put things together and take apart, be enchanted by stories.

These narratives suggested that pre-service English teachers had the opportunity to keep in close touch with small children by communicating with them and they enriched their experiences about child psychology.

\section{Discussion}

For the successful teaching of English in kindergartens, it is essential for the teacher to understand the young learners' characteristics, instincts, and interests in their cognitive, linguistic, and emotional aspects, because this will play a crucial role in how the teacher builds a lesson, how he or she can make sure that the young learners are fully involved in the learning process, how he or she achieves the objectives of a lesson, and how they respond.

More than $90 \%$ of the participants strongly agreed that doing activities with English, moving around, having fun, and interacting with others in the classroom enrich the learning process. Young learners tend to have short attention spans and a lot of physical energy. In addition, children are very much linked to their surroundings and are more interested in the physical and the tangible. Getting support from the teacher can facilitate students' English learning and students should study with their own learning styles.

Further, most of the participants supported the idea that children learn English not the same way as they learn their mother tongue. The findings from the participants' beliefs about children's' English development appear to be compatible with the literature on children's 
second or foreign language learning (Brown, 2000; Moon, 2000; Vale \& Feunteun, 2003). For instance, Moon (2000) suggested that physical activities such as playing games, making things, action songs, rhymes, and drama can provide excellent contexts for children to learn English.

In addition, participants believed that it may be helpful to view children's native language as a useful resource for checking understanding. Using English in the classroom can be challenging for pre-service English teachers. For this reason, most of the participants indicated that they used English less than $40 \%$ of the time during the lessons.

The majority considered the use of role-playing, games, and multimedia equipment to be essential. Most of the participants said that they focused primarily on spoken English and the use of songs and games. It was also stated that play-based activities resulted into an enjoyable climate with a strong focus on communication and movement.

The participating pre-service English teachers complained about the inadequate and inappropriate materials that were available in the classrooms. There are no locally produced materials for this age group of learners so most of the participants said that they looked for materials on the Internet or from other sources. They produced their own worksheets and exercises. The most common topics that the participating pre-service English teachers worked with were colors, numbers, body parts, food, animals, family members and some simple adjectives such as tall / short, big / small.

The participants reported that when students are asked to learn in a way that makes them uncomfortable, they experience stress. In a classroom where a student's learning style is never included, that student is constantly operating under stress, and learning is likely to be seriously affected. Similarly, when students know that you are not going to get angry, you are supportive and understanding, then the reaction from the young learners will be nice and effective in terms of motivation (Lile, 2002). Most of the participants reflected ideas in this way.

Without exception, the participants indicated that community service learning had been valuable for the development of their teaching skills and confidence. All the themes were evident in the data and the results of the analysis indicated that difficulties facing pre-service English teachers in teaching young learners can be eliminated and experiences gained through community service learning will be precious for them in their teaching careers.

\section{Conclusion}

In recent years there has been growing interest in offering English to children at younger ages. This trend has also taken hold in Turkey and an increasing number of schools and even some preschools are beginning to offer English at early ages. The outcomes of this exploratory study yielded that teaching English to young learners in kindergartens is very fruitful due to the classroom practices through community service learning. These positive findings corroborated with the previous studies (Breslin et al., 2008). The results of these studies indicate that more emphasis needs to be placed on preparing teachers for the challenges of today's English classrooms. It is hugely important that children's first years of English instruction are positive and successful and teachers play a key role in their pupil's learning. So it is essential that pre-service English teachers are well-trained in teaching young learners and are able to make enough practice under appropriate conditions prepared for them. 
In this study it is suggested that this chance can be given to them through community service learning. The participating pre-service teachers complained about the crowdedness of the classes and inadequate and inappropriate materials that were available for young learners in their school. Teachers in the youngest grades must deal with the shortage of teaching materials and spend precious time on finding and creating their own materials. The findings in this study reinforced the importance of 'play' which is considered to be a powerful and amusing learning experience promoting oral communication and interaction (Griva \& Sivropoulou, 2009). Yolageldili and Arıkan (2010) state that teaching young learners requires special efforts and includes challenges. Moreover, it was highlighted that the students experienced no uncertainty and anxiety when participating in creative games, due to the positive and playful classroom climate.

Regarding the fact that, there have been limited amount of research studies in teaching English to young learners in Turkey, this study attempted to contribute to the field through examining the difficulties facing pre-service English teachers in teaching young learners and reflecting their experiences gained through community service learning. Community service learning appears to have considerable potential as a method to achieve important goals of teacher education. Initial research results, teacher educators and pre-service teachers all suggest that service learning can be a powerful learning experience.

\section{References}

Anderson, J. \& Guest, K. (1993, April). Linking campus and community: Seattle University's community service internship for preservice teachers. Paper presented at the National Service-learning Conference. Minneapolis, MN.

Biricik, E. \& Özkan, Y. (2012). The Role of Teacher Attitude in Preschool Language Education. Çukurova University Faculty of Education Journal, 41(1), 70-86.

Boyle-Baise, L. (1997). Community service learning for multicultural education: An exploratory study with preservice teachers. Paper presented at the College and University Faculty Assembly of the National Council for the Social Studies, Cincinnati, $\mathrm{OH}$.

Breslin, C. M., Morton, J. R. \& Rudisill, M. E. (2008). Implementing a physical activity curriculum into the school day: Helping early childhood teachers meet the challenge. Early Childhood Education Journal, 39(5), 429-437.

Brown, D. (2000). Teaching by principles: An interactive approach to language pedagogy (4th ed.). White Plains, New York: Longman.

Cairn, R. W. \& Kielsmeier, J. C. (Eds.). (1991). Growing hope: A sourcebook on integrating youth service into the school curriculum. Roseville, MN: National Youth Leadership Council.

Cameron, L. (2001). Teaching Languages to Young Learners. UK: Cambridge University Press.

Chambers, G. N. (1999). Motivating Language Learners. UK: Multilingual Matters Ltd

Closson, R. \& Mullins Nelson, B. (2009). Teaching social justice through community engagement. International Journal of Scholarship of Teaching and Learning, 3(1), 120.

Creswell, J. (2002). Educational research: Planning, conducting, and evaluating qualitative and qualitative research. Upper Saddle River, N. J.:Merrill.

Griva, E. \& Sivropoulou, R. (2009). Implementation and Evaluation of an Early Foreign Language Learning Project in Kindergarten. The Early Childhood Journal,37(1), 7987. 
Koller, M. K. (2006). Editor's notes. English Teaching Forum, 44(2), 1.

Krashen, S., Long, M. \& Scarcella, R. (1979). Age, rate, and eventual attainment in second language acquisition. TESOL Quarterly, 13, 573-582.

Lile, W. T. (2002). Motivation in the ESL Classroom. TESL Journal 8, 1.

Long, M. (1990). Maturational constraints on language development. Studies in Second Language Acquisition, 12, 251-285.

Ministry of National Education (2013). Elementary Schools Curriculum for Teaching English. Ankara: Board of education of Ministry of National Education.

Moon, J. (2000). Children learning English. Oxford: Macmillan Heinemann.

Read, C (2005) Managing Children Positively, English Teaching Professional, Issue 38 (18), Modern English Publishing.

Root, S. (1997). School-based service: A review of research for teacher educators. In Erickson, J. A., \& Anderson, J. B. (eds.). Learning with the Community: Concepts and Models for Service-Learning in Teacher Education. Washington, D. C.: American Association for Higher Education.

Scott, W. A. \& Ytreberg, L. H. (1990). Teaching English to Children. London: Longman.

Scott, W. A. \& Ytreberg, L. H. (2001). Teaching English to Children. (14th ed.) New York: Longman.

Seigel, S. (1995). Community Service Learning As Empowered Pedagogy: Implications for Middle School Teachers. Unpublished doctoral dissertation, University of Massachusetts at Amherst.

Shin, J. K. (2006). Ten helpful ideas for teaching English to young learners. English Teaching Forum, 44(2), 2-13.

Strage, A. (2004). Long-term academic benefits of service learning: When and where do they manifest themselves? College Student Journal, 38(2), 257-261.

Vale, D. \& Feunteun, A. (2003). Teaching children English. Cambridge, U.K.: Cambridge University Press.

Wade, R. C. (1995). Developing active citizens: Community service-learning in social studies teacher education. Social Studies, 86(3), 122-128.

Wade, R. C. (1997). Empowerment in Student Teaching Through Community Service Learning. Theory into Practice, 36(3), 184-191.

Wade, R. C. \& Yarbrough, D. B. (1997). Community service-learning in student teaching: Toward the development of an active citizen. Michigan Journal of Community Service-Learning, 4, 42-55.

Weglarz, S. G. \& Seybert, J. A. (2004). Participant perceptions of a community college service-learning program. Community College Journal of Research and Practice, 28, 123-132.

Yolageldili, G. \& Arıkan, A. (2010). Effectiveness of using games in teaching grammar to young learners. Elementary Education Online, 10(1), 219-229. 